\title{
Survivability of Lactobacillus acidophilus and quality attributes of puffed pounded-unripe rice supplemented with probiotics using a fluidized-bed coating method
}

\author{
1,*Duangkhamchan, W. and ${ }^{2}$ Itsaranuwat, P. \\ ${ }^{1}$ Research Unit of Process Design and Automation, Faculty of Engineering, Mahasarakham University, \\ Kamriang, Kantarawichai, Maha Sarakham 44150, Thailand \\ ${ }^{2}$ Department of Biotechnology, Faculty of Technology, Mahasarakham University, Kamriang, \\ Kantarawichai, Maha Sarakham 44150, Thailand
}

\begin{abstract}
Article history:
Received: 20 May 2020

Received in revised form: 22 July 2020

Accepted: 2 January 2021

Available Online: 3 January 2021
\end{abstract}

\section{Keywords:}

Lactobacillus acidophilus,

Wet granulation,

Survivability,

Value-added cereal

DOI:

https://doi.org/10.26656/fr.2017.4(S4).001

\begin{abstract}
Value-added breakfast cereals are receiving increased interest due to changes in lifestyles and modern trends of health awareness among consumers. Among various cereal grains, puffed pounded-unripe rice (PPUR) was chosen because of its excellent health beneficial properties. Feasibility of supplementing the probiotic bacteria Lactobacillus acidophilus (LA5) into PPUR was investigated using a fluidized-bed coating method. Suitable fermentation conditions were tested based on a $\mathrm{pH}$ criterion of 4.5. Three types of cell host solutions as sucrose, skim milk and maltodextrin were examined as suitable carriers, and optimal coating condition was determined. Product qualities were evaluated for stability. Results showed that milk fermented for $24 \mathrm{hrs}$ gave the highest viable cell count of approximately $10^{9}$ to $10^{10} \mathrm{CFU} / \mathrm{mL}$ when optimally mixed with distilled water at milk: water ratio of 45:105. Skim milk was determined as the most suitable host giving the highest retention of LA5 cell count. Coating condition at a feed rate of $10 \mathrm{~mL} / \mathrm{min}$, coating time of $5 \mathrm{mins}$ and constant temperature at $50^{\circ} \mathrm{C}$ gave the highest survival rates of LA5. Moisture contents and water activity $\left(\mathrm{a}_{\mathrm{w}}\right)$ values of all coated products ranged from $3.38-3.72 \% \mathrm{wb}$ and $0.201-0.232$, respectively. Regarding textural properties, coated PPUR showed increased hardness and crispiness compared with uncoated samples, while the variation of coating conditions had no significant effects. Dynamic changes in viable LA5 cell count, textural properties, $a_{w}$, peroxide value and thiobarbituric acid values fitted well with various kinetic orders. Findings indicated the feasibility of adding probiotics to dry products associated with suitable coating solution and offered guidance for product development and process design.
\end{abstract}

\section{Introduction}

Nowadays, customers are increasingly attracted by the additional health-associated benefits offered by functional foods beyond meeting basic nutritional needs (Hasler, 2002). Probiotic-enriched foods have become a well-known group that has recently emerged as a significant product category in food markets, especially those claiming to promote gastrointestinal health (de Vrese and Schrezenmeir, 2008; Bosnea et al., 2017).

Probiotics comprise live microorganisms that actively contribute to gut health. They can be delivered using a food matrix as a vehicle to the desired destination with a controlled-released time. To meet most health benefits, viable probiotic cell counts should be sufficient at the time of consumption or the expiration date (Bosnea et al., 2017). Therefore, product development has challenged researchers to design appropriate food vehicles for probiotics.

Probiotic products have been developed to meet consumers' lifestyles in various food matrices, from those with high water activities and an expected shelflife of weeks such as yogurt, to dry products with low water activities and an expected shelf-life of months, e.g. infant formula (Weinbreck et al., 2010). Dairy products have successfully emerged in functional food markets but due to their short shelf-life and strict storage conditions, dry products with prolonged shelf-life are often an alternative choice for consumers. However, reduced probiotic survival is affected by food matrix and 
storage conditions such as temperature, humidity and atmospheric oxygen (Teixeira et al., 1995; Anal and Singh, 2007; Weinbreck et al., 2010) and still needs to be addressed.

To protect probiotic cells against severe environmental factors, encapsulation techniques have been successfully applied to liquid-based products such as dairy products (Kailasapathy, 2006; Krasaekoopt et al., 2003; Weinbreck et al., 2010). However, scant information is available concerning applications of dry food products with low water activity. Therefore, a greater understanding regarding the feasibility of adding probiotics to a dry food matrix such as breakfast cereals would be interesting for product development.

Among several encapsulation techniques, fluidizedbed coating is an effective method to successfully add natural extracts to cereals as reported in (Palamanit et al., 2013; Duangkhamchan and Siriamornpun, 2015; SolílsMorales et al., 2009). However, no research exists on trials focusing on improving functional properties of breakfast cereals by addition of probiotics. Therefore, here, a top-spray fluidized-bed coating technique was applied for coating puffed pounded-unripe rice with a solution containing viable probiotics (Lactobacillus acidophilus, LA5). Optimal fermentation of milk, probiotic concentration and carrier as well as suitable coating conditions were examined. Stability of viable microorganisms and quality attributes of coated puffed pounded-unripe rice were assessed during storage.

\section{Materials and methods}

\subsection{Strains}

Lactobacillus acidophilus (LA5) was used as the probiotic strain. The culture was prepared as previously described by Dimitrellou et al. (2016) and then used to inoculate the feed media.

To activate the cells, LA5 was cultured in MRS broth at $37^{\circ} \mathrm{C}$ for $16-18$ hrs. About $5 \%$ of activated LA5 was transferred into milk sterilized at $110^{\circ} \mathrm{C}$ for 5 mins. Sterile reconstituted milk of $50 \mathrm{~mL}$ was inoculated under anaerobic condition $\left(5 \% \mathrm{CO}_{2}\right)$ at $37^{\circ} \mathrm{C}$ for $18-24 \mathrm{hrs}$ and subsequently used as a starter.

\subsection{Fermentation of milk}

Milk (100 ml) was pasteurized at $85^{\circ} \mathrm{C}$ for 15 mins. After cooling to ambient temperature, LA5 was added to the pasteurized milk and then inoculated under anaerobic condition $\left(5 \% \mathrm{CO}_{2}\right)$ at $37^{\circ} \mathrm{C}$ for various fermentation periods of $0,3,6,9,12,18$ and $24 \mathrm{hrs}$. Strain growth was analyzed by the pour plate method in MRS agar. The $\mathrm{pH}$ was recorded at each fermentation period, and time taken to reach 4.2-4.6 was considered as the optimal fermentation period (Dimitrellou et al., 2016).

\subsection{Determination of optimal concentration of coating solution}

Fermented milk obtained from section 2.2 was mixed with distilled water at various mixing ratios, including 45:105, 60:90 and 75:75 (fermentedmilk:distilled-water). The mixtures were tested in the top -spray fluidized-bed coating equipment as shown in Figure 1. All coating parameters employed in this section were kept constant: a feed rate of $8 \mathrm{ml} / \mathrm{min}$, coating time of 15 mins and air temperature of $50^{\circ} \mathrm{C}$. The mixture with the highest cell count was further used as a suitable coating solution.

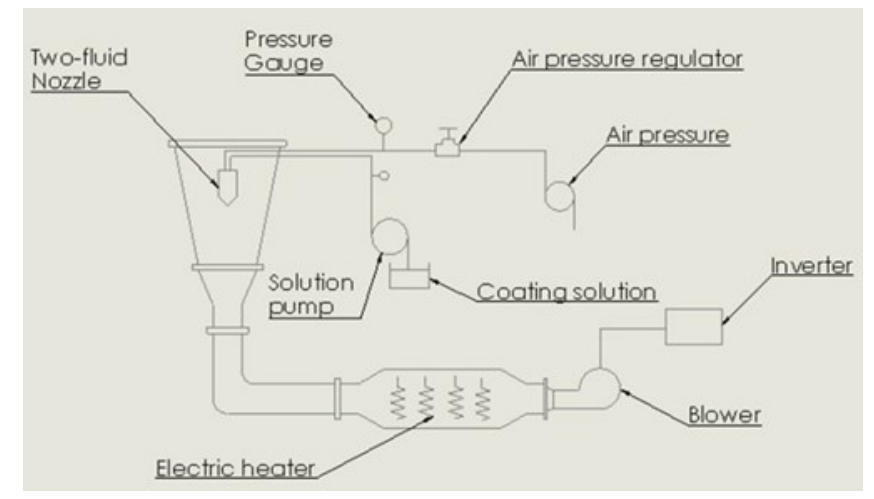

Figure 1. Top-spray fluidized-bed equipment (Duangkhamchan and Siriamornpun, 2015).

\subsection{Determination of optimal carrier}

To enhance the survival of microorganisms entrapped on the surface of the puffed pounded-unripe rice (PPUR) sample, a carrier was selected from three solutions of skim milk, maltodextrin and sucrose with a concentration of $10 \%(\mathrm{w} / \mathrm{v})$. For each solution, LA5 was added with an initial number of $10^{9}-10^{10} \mathrm{CFU} / \mathrm{mL}$, and subsequently subjected to the fluidized-bed coating process under constant operating parameters including air temperature $50^{\circ} \mathrm{C}$, coating solution feed rate $5 \mathrm{~mL} /$ min and coating time 10 mins. The survival of LA5 after coating was analyzed using MRS agar. Moisture content (MC, wet basis), water activity $\left(a_{w}\right)$ and textural properties (hardness and crispiness) were also determined and used as criteria for selecting a suitable carrier.

\subsection{Optimal fluidized-bed coating condition}

Operating parameters in the fluidized-bed coating process were selected as coating solution feed rate (6.7, 7.5 and $\left.10 \mathrm{ml} \mathrm{min}^{-1}\right)$ and coating time (5, 7.5 and 10 mins) to compare results of coating yield or the total amount of coating solution $(50 \mathrm{~mL})$ used in each experiment. Corresponding coating conditions are 
presented in Table 1. Because the survival of probiotics is sensitive to heat, the air temperature was kept constant at $50^{\circ} \mathrm{C}$ during the coating process. Optimal fluidizedbed coating condition was determined based on survival percentage, physical and textural properties.

Table 1. Coating conditions for determining optimal fluidizedbed coating parameters.

\begin{tabular}{cc}
\hline Spraying time $(\mathrm{min})$ & Feed rate $(\mathrm{mL} / \mathrm{min})$ \\
\hline 5 & 10 \\
7.5 & 6.7 \\
10 & 5 \\
\hline
\end{tabular}

2.6 Stability of PPUR product supplemented with probiotics during storage

PPUR was kept in aluminium foil for stability analysis during the storage time of 28 days. Following the method of Yan et al. (2014), mean survival ratios ( $N$ / $N_{0}$ ) were fitted to a temperature-time model describing viable LA5 as a function of storage time and expressed as follows:

$$
\frac{d\left(\frac{N}{N_{0}}\right)}{d t}=-k\left(\frac{N}{N_{0}}\right)^{1-n}
$$

In this equation, $N$ and $N_{0}$ denote LA5 cell counts at a specific time ( $t$, day) and initial storage time, respectively where $k$ is the rate constant $\left(\right.$ day $\left.^{-1}\right)$. The rate constant $k$ was determined at different kinetic orders $(n=$ $0,0.5,1,1.5,2)$ by converting the kinetic equation to a logarithm form (Yan et al., 2014). The linear relation was then employed to estimate all constants in equations 2 and 3 as expressed by:

$$
\begin{aligned}
& \ln \left(\frac{N}{N_{0}}\right)=-k t+c \quad(n=1) \\
& \left(\frac{N}{N_{0}}\right)^{1-n}=-k t+c \quad(n \neq 1)
\end{aligned}
$$

Among the different kinetic orders tested, the best fit was chosen based on the highest coefficient of determination $\left(\mathrm{R}^{2}\right)$.

Kinetic equations 1-3 were also employed for other attributes including $\mathrm{a}_{\mathrm{w}}$, hardness, stickiness, peroxide value (PV) and thiobarbituric acid (TBA) with the replacement of their ratios between values at specific and initial times.

\subsection{Quality attributes of PPUR supplemented with LA5}

\subsubsection{Moisture content}

About $3 \mathrm{~g}$ of PPUR was dried in a hot-air oven at $105^{\circ} \mathrm{C}$ for $72 \mathrm{hrs}$ to reach equilibrium moisture content. Based on the standard method of AOAC (AOAC, 1995), moisture contents of samples were calculated using the initial weight and weight at equilibrium.

\subsubsection{Water activity $\left(a_{w}\right)$}

Water activity of PPUR was measured using a water activity meter (Aqualab, Decagon, USA).

\subsubsection{Cell survival rate}

About $10 \mathrm{~g}$ of PPUR were ground and then added to $90 \mathrm{~mL}$ of $0.1 \%$ peptone. The mixture was held at room temperature for 15 mins and then shaken for 2 mins. Subsequently, serial dilution was conducted and LA5 was enumerated using the pour plate method with MRS agar, inoculated at $37^{\circ} \mathrm{C}$ for $24-48 \mathrm{hrs}$. Three replications were conducted and the average cell survival rate was presented in CFU/mL.

\subsubsection{Rancidity analysis}

\subsubsection{Analysis of peroxide value}

The coated PUR samples were expected to be protected against the atmosphere; therefore, degree of hydroxide formation of the samples, considered as the rancidity index, was analyzed during storage. The peroxide value (PV) was measured according to the method proposed by Krik and Sawyer (1991) with slight modifications. Briefly, approximately four grams of blended PPUR were mixed with $10 \mathrm{~mL}$ chloroform and $15 \mathrm{~mL}$ glacial acetic acid and then shaken vigorously for $30 \mathrm{~s}$. Meanwhile, $1 \mathrm{~mL}$ of potassium iodide was dropped wisely and subsequently kept in the dark for $5 \mathrm{~min}$. In the final step, the mixture was titrated with $0.01 \mathrm{M}$ sodium thiosulphate solution and a blank. The PV was calculated by:

$$
P V=\frac{\left(V_{1}-V_{0}\right) T \times 10^{3}}{M}
$$

where $\mathrm{V}_{1}$ and $\mathrm{V}_{0}(\mathrm{~mL})$ denote the volume of sodium thiosulphate solution and a blank without sample, respectively, $\mathrm{M}(\mathrm{g})$ the sample mass, and $\mathrm{T}$ the molarity of sodium thiosulphate. The PV was measured as three replicates and the average value was expressed in millequivalent of active oxygen per one kilogram $(\mathrm{mEq} /$ active $\mathrm{O}_{2} / \mathrm{kg}$ ).

\subsubsection{Analysis of 2-thiobarbituric acid (TBA)}

In addition to PV, 2-thiobarbituric acid (TBA) of PPUR was measured based on the spectrophotometry method (Kirk and Sawyer, 1991). TBA solution was first prepared by dissolving $200 \mathrm{mg}$ of TBA in butanol (100 $\mathrm{mL})$. It was then filtered and stored in a fridge $\left(4 \pm 1^{\circ} \mathrm{C}\right)$ for 2-3 days before use. Approximately $50 \mathrm{~g}$ of blended PPUR sample was added to the TBA solution. The mixture was heated in boiling water for $10 \mathrm{mins}$ and then cooled to room temperature. A Beckman DU-640 Spectrophotometer (Beckman Coulter, Fullerton, USA) was employed to record the absorbance of the sample 
mixture at $530 \mathrm{~nm}\left(\mathrm{~A}_{\mathrm{s}}\right)$ as well as a blank $\left(\mathrm{A}_{0}\right)$. The TBA value was calculated by:

$$
T B A=\frac{50 \times\left(A_{s}-A_{b}\right)}{C}
$$

where $\mathrm{C}$ represents sample mass $(\mathrm{mg})$. Based on the reaction of malonaldehyde (MDA) and thiobarbituric acid, TBA values averaged from three replications were expressed as mg of MDA per $100 \mathrm{~g}$ sample.

\subsubsection{Textural analysis}

Textural properties including hardness and crispiness of coated PPUR were measured by using a TA-XT2 $\mathrm{i}$ Texture Analyzer (Stable Microsystems Ltd., UK) equipped with a 5-blade Krammer shear cell. The test was performed by compressing the samples $(200 \mathrm{~g})$ at a speed rate of $1 \mathrm{~mm} \mathrm{~s}^{-1}$ until the blades completely cut all pieces of PPUR. Peak force (g) and the number of peaks obtained from the force-deformation curve were recorded and expressed as the hardness and crispiness, respectively. An average of five measurements for each sample was presented.

\section{Results and discussion}

In this work, the feasibility of adding LA5 cell onto PPUR as the breakfast cereal product was analyzed. Experimental scenarios were orderly conducted to examine the optimal process. The fermented milk was first prepared with the suitable condition under which its $\mathrm{pH}$ reached 4.5 and subsequently mixed with distilled water as the base coating solution. Due to heat sensibility, the type of carrier was suitably selected based on LA5 cells retained after exposure to heat in a fluidized bed coating process. Next, the appropriate coating parameters were determined in order to obtain good physical and textural properties with remaining a maximum number of living bacteria. Eventually, dynamic changes in all attributes during storage were analyzed.

\subsection{Optimal condition for preparing fermented milk}

Figure 2 shows variations of LA5 growth (log CFU/ $\mathrm{mL}$ ) and $\mathrm{pH}$ of fermented milk at different fermentation times (hr). The $\mathrm{pH}$ value played an important role in LA5 growth, decreasing from 6.82 to 4.5 at fermentation time of $24 \mathrm{hrs}$, while the growth of LA5 increased from 7.55 to $12.68 \log \mathrm{CFU} / \mathrm{mL}$ corresponding to a suitable $\mathrm{pH}$ of 4.5 at fermentation time of $24 \mathrm{hrs}$. This was considered as the optimal fermentation condition that produced the highest number of microorganisms with $\mathrm{pH}$ in a suitable range of 4.2-4.6 (Dimitrellou et al., 2016).

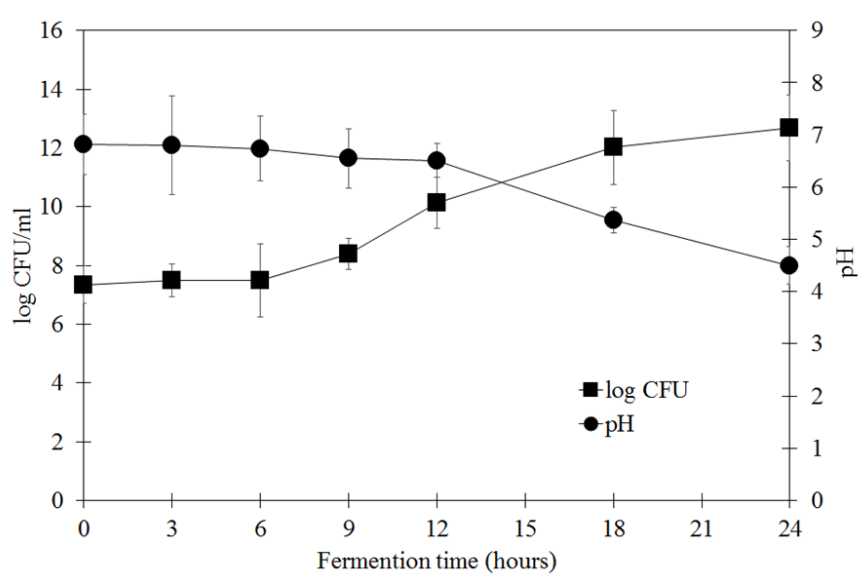

Figure 2. Optimal condition for preparing fermented milk containing LA5.

\subsection{Optimal concentration of coating solution}

Table 2 shows the survival percentage of LA5 and moisture content of PPUR coated with different ratios of fermented milk and distilled water. The ratio with the highest percentage of LA5 survival after the coating process was chosen as the most suitable. According to results in Table 2, the initial count of LA5 and moisture content of PPUR were not significantly different, ranging from $0.97 \times 10^{10}$ to $1.48 \times 10^{10} \mathrm{CFU} / \mathrm{mL}$ and 3.86 to $4.53 \%$ wb, respectively.

After coating, viable LA5 count changed with different amounts of distilled water in the solution, ranging from $3.82 \times 10^{8} \mathrm{CFU} / \mathrm{mL}$ to $5.21 \times 10^{8} \mathrm{CFU} / \mathrm{mL}$. Survival increased at higher fermented milk ratios, resulting in higher cell count. Maximum LA5 cell viability was found when using $75 \mathrm{~mL}$ of fermented milk followed by $45 \mathrm{~mL}$ and $60 \mathrm{~mL}$. Table 2 also shows the survival percentage of LA5. This decreased as water reduced from $105 \mathrm{~mL}$ to $90 \mathrm{~mL}$. This observation could be attributed to higher water evaporated, resulting in lower temperature for the cells. Increase in water also increased the MC values of the samples but they remained at a safe level.

Furthermore, the optimal ratio of fermented milk and distilled water was selected based on the highest survival percentage of the cells after exposure to heat in the coating process. Solutions with fermented milk: water ratios of 45:105 and 60:90 equally gave the maximum survival percentage but for economic concerns, the ratio with a lower amount of fermented milk was selected as more suitable. Therefore, the ratio of fermented milk and distilled water at 45:105 was further used for the coating solution.

\subsection{Optimal carrier}

The major purpose of encapsulation is to protect bacteria against severe environmental factors. 
Table 2. Survival percentage of LA5 and moisture content before and after fluidized-bed coating with different concentrations of fermented milk.

\begin{tabular}{cccccc}
\hline FM: water & \multicolumn{3}{c}{ Before coating } & \multicolumn{3}{c}{ After coating } \\
\hline$(\mathrm{mL}: \mathrm{mL})$ & Survival $^{\mathrm{ns}}(\mathrm{CFU} / \mathrm{mL})$ & $\mathrm{MC}^{\mathrm{ns}}(\% \mathrm{wb})$ & Survival $^{(\mathrm{CFU} / \mathrm{mL})}$ & Survival $(\%)$ & $\mathrm{MC}(\% \mathrm{wb})$ \\
\hline $45: 105$ & $0.97 \pm 0.92 \times 10^{10}$ & $4.24 \pm 0.26$ & $3.82 \pm 0.37^{\mathrm{a}} \times 10^{8}$ & $4.02 \pm 0.54^{\mathrm{b}}$ & $4.75 \pm 0.11^{\mathrm{b}}$ \\
$60: 90$ & $1.28 \pm 0.25 \times 10^{10}$ & $3.86 \pm 0.24$ & $3.90 \pm 0.71^{\mathrm{a}} \times 10^{8}$ & $3.05 \pm 0.04^{\mathrm{a}}$ & $4.55 \pm 0.17^{\mathrm{b}}$ \\
$75: 75$ & $1.48 \pm 0.28 \times 10^{10}$ & $4.53 \pm 0.19$ & $5.21 \pm 0.51^{\mathrm{b}} \times 10^{8}$ & $3.56 \pm 0.33^{\mathrm{b}}$ & $3.98 \pm 0.08^{\mathrm{a}}$ \\
\hline
\end{tabular}

Values with different superscript within the same column are significantly different.

FM, Fermented milk; ns, not significant.

Table 3. Survival percentage of LA5 and moisture content before and after fluidized-bed coating with different carriers.

\begin{tabular}{lccccc}
\hline \multirow{2}{*}{ Carrier } & \multicolumn{3}{c}{ Before coating } & \multicolumn{3}{c}{ After coating } \\
\cline { 2 - 6 } & Survival $^{\mathrm{ns}}(\mathrm{CFU} / \mathrm{mL})$ & $\mathrm{MC}^{\mathrm{ns}}(\% \mathrm{wb})$ & Survival $(\mathrm{CFU} / \mathrm{mL})$ & Survival $(\%)$ & $\mathrm{MC}(\% w b)$ \\
\hline Sucrose & $3.74 \pm 0.49^{\prime} 10^{10}$ & $4.37 \pm 0.16$ & $2.49 \pm 0.28^{\mathrm{b} \prime} 10^{8}$ & $0.66 \pm 0.01^{\mathrm{b}}$ & $4.35 \pm 0.21$ \\
Skim milk & $3.03 \pm 0.53^{\prime} 10^{10}$ & $4.34 \pm 0.17$ & $2.51 \pm 0.29^{\mathrm{b} \prime} 10^{8}$ & $0.82 \pm 0.09^{\mathrm{c}}$ & $4.55 \pm 0.13$ \\
Maltodextrin & $3.26 \pm 0.10^{\prime} 10^{10}$ & $4.42 \pm 0.09$ & $1.10 \pm 0.38^{\mathrm{a} \prime} 10^{8}$ & $0.33 \pm 0.15^{\mathrm{a}}$ & $3.98 \pm 0.18$ \\
\hline
\end{tabular}

Values with different superscript within the same column are significantly different. ns, not significant.

Appropriate cell carriers contribute to survive during processing and storage and time of release (Anal and Singh, 2007; Champagne and Fustier, 2007). Table 3 presents the survival percentage of LA5 as affected by cell-carrier type.

Fluidized-bed coating is a process in which heat and mass transfer take place simultaneously in one operation. At intermediate heat $\left(50^{\circ} \mathrm{C}\right)$, bacteria require a suitable host during the process so that they can survive until the encapsulation process is complete. Here, three types of carriers as sucrose, milk powder and maltodextrin were mixed with fermented milk containing LA5 at 3.2$3.7 \times 10^{10} \mathrm{CFU} / \mathrm{mL}$, as shown in Table 3 . After coating at $50^{\circ} \mathrm{C}$, survival percentages of LA5 were significantly different, decreased after coating as normally found for lactic bacteria which is sensible to heat (Zhang et al., 2018). Coating solution mixed with skim milk gave the highest survival percent of 0.82 , implying that skim milk was a suitable host during the process, followed by sucrose and maltodextrin with survival percentages of 0.66 and 0.33 , respectively. A plausible explanation for this result was that protein-based materials have higher oxygen and moisture barriers as well as heat resistance (Krochta and Nisperos-Carriedo, 1994; Gennadios, 2002). This is consistent with Dimitrellou et al. (2016) stating that skim milk could protect lactic bacteria during spray drying due to its heat protective capacity (Corcoran et al., 2004). The amount of water used for each coating solution was kept constant; therefore, moisture content of coated PPUR was insignificant (3.98-4.55\%wb).

\subsection{Effect of fluidized-bed coating on survival percentage of LA5}

The most suitable carrier as skim milk selected in the previous section was mixed with the coating solution, fermented milk and distilled water at the ratio of 45:105 to determine the optimal coating time. Table 4 shows the survival percentage of LA5 and moisture content before and after coating at different spraying times and feed rates. Each batch approximately contained the same initial count of LA5 (or the same amount of coating solution). The number of LA5 contained in the coating solution was $2.62-3.78 \times 10^{10} \mathrm{CFU} / \mathrm{mL}$. As bacteria LA5 are sensitive to heat, their survival decreased dramatically to $3.13-6.00 \times 10^{8} \mathrm{CFU} / \mathrm{mL}$ after coating. This is commonly observed in many works when bacteria cells are subjected to heat; for instance, Paéz et al. (2012) presented the effects of heat treatment on the survivability of lactobacilli. With the variation of exposure times to heat, the coating treatment with shortest spraying time gave the highest survival percentage $(1.60 \%)$, while LA5 bacteria were mostly destroyed after exposure to heat during $10 \mathrm{mins}$ of spraying time at $99.17 \%$.

\subsection{Effect of fluidized-bed coating on physical and textural properties}

Table 5 shows the physical and textural properties of PPUR coated at different coating conditions. Adding coating solution onto the sample surface slightly increased the moisture content; however, variations in spraying time and feed rate did not significantly affect the final MC.

By contrast, water activity decreased after coating but ranged in the safe level for dry products at 0.20-0.23. Typical properties of snack foods as hardness and crispiness of coated PPUR were determined. Hardness was not affected by process conditions, while crispiness of coated PPUR increased significantly, compared with 
Table 4. Survival percentage of LA5 and moisture content before and after fluidized-bed coating with different operating conditions.

\begin{tabular}{ccccccc}
\hline \multicolumn{2}{c}{ Operating Condition } & \multicolumn{2}{c}{ Before coating } & \multicolumn{3}{c}{ After coating } \\
\hline Spraying time $(\mathrm{min})$ & Feed rate $(\mathrm{mL} / \mathrm{min})$ & Survival $^{\mathrm{ns}}(\mathrm{CFU} / \mathrm{mL})$ & $\mathrm{MC}^{\mathrm{ns}}(\% \mathrm{wb})$ & Survival $(\mathrm{CFU} / \mathrm{mL})$ & Survival $(\%)$ & $\mathrm{MC}(\% \mathrm{wb})$ \\
\hline 5 & 10 & $3.78 \pm 0.99^{\prime} 10^{10}$ & $3.05 \pm 0.08$ & $6.00 \pm 0.39^{\mathrm{b} \prime} 10^{8}$ & $1.60 \pm 0.11^{\mathrm{c}}$ & $3.13 \pm 0.12$ \\
7.5 & 6.7 & $2.62 \pm 0.31^{\prime} 10^{10}$ & $2.92 \pm 0.10$ & $2.85 \pm 0.11^{\mathrm{a} \prime} 10^{8}$ & $1.08 \pm 0.05^{\mathrm{b}}$ & $3.39 \pm 0.31$ \\
10 & 5 & $3.74 \pm 0.49^{\prime} 10^{10}$ & $3.12 \pm 0.11$ & $3.13 \pm 0.60^{\mathrm{a}} 10^{8}$ & $0.83 \pm 0.11^{\mathrm{a}}$ & $3.25 \pm 0.14$ \\
\hline
\end{tabular}

Values with different superscript within the same column are significantly different. ns, not significant.

Table 5. Physical and textural properties affected by fluidized-bed coating conditions.

\begin{tabular}{|c|c|c|c|c|c|}
\hline \multicolumn{2}{|c|}{ Operating Condition } & $\mathrm{MC}(\% \mathrm{wb})$ & $\operatorname{Hardness}^{\text {ns }}(\mathrm{N})$ & Crispiness (no. of peaks) & Water activity $\left(\mathrm{a}_{\mathrm{w}}\right)$ \\
\hline Spraying time (min) & Feed rate $(\mathrm{mL} / \mathrm{min})$ & & & & \\
\hline Uncoated & Uncoated & $2.68 \pm 0.44^{\mathrm{a}}$ & $248.87 \pm 13.43$ & $66.67 \pm 5.86^{\mathrm{a}}$ & $0.2672 \pm 0.02771^{\mathrm{b}}$ \\
\hline 5 & 10 & $3.52 \pm 0.25^{\mathrm{b}}$ & $244.75 \pm 12.74$ & $81.33 \pm 3.79^{\mathrm{b}}$ & $0.2010 \pm 0.00361^{\mathrm{a}}$ \\
\hline 7.5 & 6.7 & $3.72 \pm 0.40^{\mathrm{b}}$ & $249.52 \pm 6.94$ & $86.33 \pm 2.08^{\mathrm{b}}$ & $0.2160 \pm 0.00624^{\mathrm{a}}$ \\
\hline 10 & 5 & $3.38 \pm 0.12^{\mathrm{b}}$ & $243.34 \pm 12.37$ & $84.00 \pm 2.00^{\mathrm{b}}$ & $0.2323 \pm 0.01739^{\mathrm{a}}$ \\
\hline
\end{tabular}

Values with different superscript within the same column are significantly different. ns, not significant.

uncoated ones (as shown in Table 5). This could be explained because the solidified coating solution layered onto the PPUR surface may result in a case-hardening effect. This finding is consistent with Duangkhamchan and Incheun (2016) presenting that significant changes in textural properties of PPUR coated by marigold extract were observed after coating. However, the varied process parameters tested did not significantly change the textural properties of coated PPUR, due to the same amount of coating solution used in this work.

\subsection{Stability of PPUR supplemented with LA5 during storage}

During storage, environmental parameters usually affect the physical, chemical and textural properties of snack products (Pathare and Byrne, 2011). An insight into kinetic behavior during storage is useful for process designers and management. Figure 3 shows the survival rate of LA5 cell supplemented in PPUR during storage of 28 days. The viability of LA5 cells decreased exponentially as a function of storage period from $6 \times 10^{8}$ $\mathrm{CFU} / \mathrm{mL}$ at the onset of the storage to $7.5 \times 10^{6} \mathrm{CFU} / \mathrm{mL}$. The viable cell count at the end of storage was not consistent with that reported in Santos Filho et al. (2019) in which LA5 remained approximately $10^{7} \mathrm{CFU} / \mathrm{mL}$ in cocoa juice after 42 days of refrigerated storage. Even though PPUR contained such low strain viability at 28 days, it was still in a range $\left(10^{6}-10^{9} \mathrm{CFU} / \mathrm{mL}\right)$ which was sufficient to obtain a beneficial result (Vinderola et al., 2000). Furthermore, microbial viability and product attributes were subjected to kinetics modeling with different orders. Based on the highest coefficient of determination $\left(\mathrm{R}^{2}\right)$, suitable choices of each attribute are presented in Table 6 . All equations with $\mathrm{R}^{2}$ values higher than 0.8 could serve as a basis for describing changes in attributes over a storage period of 28 days. All equations together with their constants are summarized in Table 7.

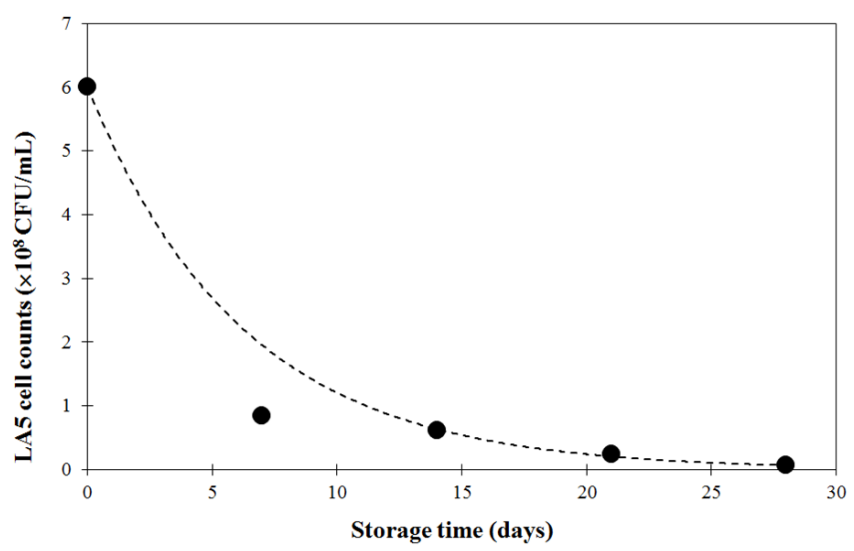

Figure 3. Kinetic behavior of LA5 viability during 28-day storage.

Table 6. Coefficients of determination $\left(\mathrm{R}^{2}\right)$ with different orders of kinetic equations.

\begin{tabular}{lccccc}
\hline \multirow{2}{*}{\multicolumn{1}{c}{ Attribute }} & \multicolumn{5}{c}{ Coefficient of determination $\left(\mathrm{R}^{2}\right)$} \\
\cline { 2 - 6 } & $0^{\text {th }}$ & $0.5^{\text {th }}$ & $1^{\text {st }}$ & $1.5^{\text {th }}$ & $2^{\text {nd }}$ \\
\hline Moisture content & 0.9709 & 0.9791 & 0.9856 & 0.9904 & 0.9935 \\
Water activity $\left(\mathrm{a}_{\mathrm{w}}\right)$ & 0.8603 & 0.8575 & 0.8549 & 0.8523 & 0.8498 \\
Hardness & 0.9331 & 0.8985 & 0.857 & 0.8116 & 0.7656 \\
Crispiness & 0.9649 & 0.9641 & 0.9631 & 0.9621 & 0.9609 \\
Population of L. acidophilus & 0.6195 & 0.7782 & 0.9514 & 0.8998 & 0.7447 \\
Peroxide value & 0.8293 & 0.8465 & 0.8627 & 0.8779 & 0.8918 \\
Thiobarbituric acid & 0.9696 & 0.9601 & 0.9478 & 0.9327 & 0.9151 \\
\hline
\end{tabular}


Table 7. Suitable kinetic equations for all attributes during 28 days of storage.

\begin{tabular}{ll}
\hline \multicolumn{1}{c}{ Attribute } & \multicolumn{1}{c}{ Model } \\
\hline MC & $\frac{M C_{0}}{M C}=-0.0133 t+1.0139$ \\
Water activity $\left(\mathrm{a}_{\mathrm{w}}\right)$ & $\frac{a_{w}}{a_{w 0}}=0.0155 t+1.0111$ \\
Hardness (H) & $\frac{H}{H_{0}}=-0.0204 t+1.035$ \\
Crispiness (C) & $\frac{C}{C_{0}}=-0.0046 t+1.0012$ \\
LA5 survival (\%) & $\frac{L A 5}{L A 5_{0}}=e^{-0.1432 t}+0.6975$ \\
Peroxide value (PV) & $\frac{P V_{0}}{P V}=-0.0134 t+1.0554$ \\
TBA & $\frac{T B A}{T B A_{0}}=0.0245 t+1.043$ \\
\hline
\end{tabular}

\section{Conclusion}

Novel breakfast cereals were developed using the top -spray fluidized-bed coating process for probiotics supplementation. A suitable $\mathrm{pH}$ of 4.5 and a fermentation time of $24 \mathrm{hrs}$ were considered to be optimal fermentation conditions, giving the highest number of microorganisms and $\mathrm{pH}$ at a suitable range of 4.2-4.6. Based on the highest survival percentage after coating, solution ratios of 45:105 and 75:75 were considered as optimal concentrations with survival percentages of 4.02 and 3.56, respectively. Among these solutions, the former was chosen with respect to economic concerns. In the coating test at $50^{\circ} \mathrm{C}$, skim milk was selected as the best host for LA5 cells as it gave the highest survival percentage after the coating process. Both hardness and crispiness of PPUR after coating increased but were not significantly affected by operating conditions. Stability analysis during storage provided suitable kinetic equations for describing product quality attributes, with $\mathrm{R}^{2}$ values mostly above 0.9 . Our findings could be used as the basis for further product development and process design.

\section{Conflict of interest}

The authors declare no conflict of interest.

\section{Acknowledgments}

Authors would like to thank Mahasarakham University Research Fund for financial support (No.5601069/2556) and Mahasarakham University Development Fund for Travel grant.

\section{References}

Anal, A.K. and Singh, H. (2007). Recent advances in microencapsulation of probiotics for industrial applications and targeted delivery. Trends in Food Science and Technology, 18(5), 240-251. https:// doi.org/10.1016/j.tifs.2007.01.004

AOAC. (1995). Official methods of analysis. $16^{\text {th }}$ ed. Washington, DC: Association of Official Agricultural Chemists.

Bosnea, L.A., Kopsahelis, N., Kokkali, V., Terpou, A. and Kanellaki, M. (2017). Production of a novel probiotic yogurt by incorporation of $L$. casei enriched fresh apple pieces, dried raisins and wheat grains. Food and Bioproducts Processing, 102, 6271. https://doi.org/10.1016/j.fbp.2016.11.010

Champagne, C.P. and Fustier, P. (2007). Microencapsulation for the improved delivery of bioactive compounds into foods. Current opinion in Biotechnology, 18(2), 184-190. https:// doi.org/10.1016/j.copbio.2007.03.001

Corcoran, B.M., Ross, R.P., Fitzgerald, G.F. and Stanton, C. (2004). Comparative survival of probiotic lactobacilli spray dried in the presence of prebiotic substances. Journal of Applied Microbiology, 96(5), 1024-1039. https:// doi.org/10.1111/j.1365-2672.2004.02219.x

de Vrese, M. and Schrezenmeir, J. (2008). Probiotics, prebiotics and synbiotics. In Stahl, U., Donalies, U.E. and Nevoigt, E. (Eds.) Food Biotechnology. Advances in Biochemical Engineering/ Biotechnology. Vol. 111, p. 1-66. Berlin, Heidelberg, Germany: Springer. https:// doi.org/10.1007/10_2008_097

Dimitrellou, D., Kandylis, P., Petrović, T., DimitrijevićBranković, S., Lević, S., Nedović, V. and Kourkoutas, Y. (2016). Survival of spray dried microencapsulated Lactobacillus casei ATCC 393 in simulated gastrointestinal conditions and fermented milk. LWT - Food Science and Technology, 71, 169174. https://doi.org/10.1016/j.lwt.2016.03.007

Duangkhamchan, W. and Incheun, S. (2016). Texture and antioxidant properties of puffed pounded-unripe rice coated by marigold extract as affected by fluidized-bed coating conditions. Key Engineering Materials, 718, 115-119. https://doi.org/10.4028/ www.scientific.net/KEM.718.115

Duangkhamchan, W. and Siriamornpun, S. (2015). Quality attributes and antioxidant content of rice coated by purple-corn cob extract as affected by coating conditions. Food and Bioproducts Processing, 96, 171-179. https://doi.org/10.1016/ j.fbp.2015.07.012 
Gennadios, A. (2002). Protein-based films and coatings. Boca Raton: CRC Press LLC. https:// doi.org/10.1201/9781420031980

Hasler, C.M. (2002). Functional foods: benefits, concerns and challenges-a position paper from the American council on science and health. Journal of Nutrition, 132(12), 3772-3781. https:// doi.org/10.1093/jn/132.12.3772

Kailasapathy, K. (2006). Survival of free and encapsulated probiotic bacteria and their effect on the sensory properties of yoghurt. LWT-Food Science and Technology, 39(10), 1221-1227. https:// doi.org/10.1016/j.lwt.2005.07.013

Kirk, R.S. and Sawyer, R. (1991). Pearson's composition and analysis of foods. $9^{\text {th }}$ ed. London: Longman Scientific and Technical.

Krasaekoopt, W., Bhandari, B. and Deeth, H. (2003). Evaluation of encapsulation techniques of probiotics for yoghurt. International Dairy Journal, 13(1), 313. https://doi.org/10.1016/S0958-6946(02)00155-3

Krochta, J.M.B. and Nisperos-Carriedo, M. (1994). Edible coatings and films to improve food quality. Switzerland: Technomic Publishing AG.

Paéz, R., Lavari, L., Vinderola, G., Audero, G., Cuatrin, A., Zaritzky, N. and Reinheimer, J. (2012). Effect of heat treatment and spray drying on lactobacilli viability and resistance to simulated gastrointestinal digestion. Food Research International, 48(2), 748754. https://doi.org/10.1016/j.foodres.2012.06.018

Palamanit, A., Soponronnarit, S., Prachayawarakorn, S. and Tungtrakul, P. (2013). Effects of inlet air temperature and spray rate of coating solution on quality attributes of turmeric extract coated rice using top-spray fluidized bed coating technique. Journal of Food Engineering, 114(1), 132-138. https://doi.org/10.1016/j.jfoodeng.2012.07.014

Pathare, P.B. and Byrne, E.P. (2011). Application of wet granulation processes for granola breakfast cereal production. Food Engineering Review, 3, 189-201. https://doi.org/10.1007/s12393-011-9043-7

Santos Filho, A.L.D., Freitas, H.V., Rodrigues, S., Abreu, V.K.G., Oliveira Lemos, T.D., Gomes, W.F., Narain, N. and Pereira, A.L.F. (2019). Production and stability of probiotic cocoa juice with sucralose as sugar substitute during refrigerated storage. $L W T$ - Food Science and Technology, 99, 371-378. https://doi.org/10.1016/j.lwt.2018.10.007

Solíls-Morales, D., Sáenz-Hernádez, C.M. and OrtegaRivas, E. (2009). Attrition reduction and quality improvement of coated puffed wheat by fluidized bed technology. Journal of Food Engineering, 93(2), 236-241. j.jfoodeng.2009.01.020

Teixeira, P.C., Castro, M.H., Malcata, F.X. and Kirby, R.M. (1995). Survival of Lactobacillus delbrueckii ssp bulgaricus following spray-drying. Journal of Dairy Science, 78, 1025-1031. https:// doi.org/10.3168/jds.S0022-0302(95)76718-2

Vinderola, C.G., Bailo, N. and Reinheimer, J.A. (2000). Survival of probiotic microflora in Argentinian yoghurts during refrigerated storage. Food Research International, 33(2), 97-102. https://doi.org/10.1016/ S0963-9969(00)00011-9

Weinbreck, F., Bodnár, I. and Marco, M.I. (2010). Can encapsulation lengthen the shelf-life of probiotic bacteria in dry product?. International Journal of Food Microbiology, 136(3), 364-367. https:// doi.org/10.1016/j.ijfoodmicro.2009.11.004

Yan, R. Huang, Z., Zhu, H., Johnson, J.A. and Wang, S. (2014). Thermal death kinetics of adult Sitophilus oryzae and effects of heating rate on thermotolerance. Journal of Stored Products Research, 59, 231-236. https://doi.org/10.1016/ j.jspr.2014.03.006

Zhang, L., Chen, X.D., Boom, R.M. and Schutyser, M.A.I. (2018). Survival of encapsulated Lactobacillus plantarum during isothermal heating and bread baking. LWT - Food Science and Technology, 93, 396-404. https://doi.org/10.1016/ j.lwt.2018.03.067 